\title{
PENGARUH MATH ANXIETY TERHADAP KEMAMPUAN PEMAHAMAN KONSEP MATEMATIS SISWA BERDASARKAN GENDER
}

\author{
Kurnia Rahmi Yuberta, Widya Setiawati, Lely Kurnia \\ IAIN Batusangkar, Sumatera Barat, Indonesia \\ kurniarahmi.y@iainbatusangkar.ac.id.
}

\begin{abstract}
Abstrak
Math anxiety often suffered by students in learning math. If it continues to appear, the students will not have a good ability on math concepts. Math concept actually is the basic ability in learning math. From a gender perspective, there is a difference in mathematics anxiety between male and female students. This research aims to seek out whether there is an influence of math anxiety on students' comprehension of math concepts based on gender. The research method was the correlational research. The research subjects were the eighth grade students of MTsN 07 Tanah Datar. The research found there is a significant negative difference between math anxiety and the ability to comprehend math concepts based on gender at the eighth grade students of MTsN 07 Tanah Datar.
\end{abstract}

Keywords: Bundo Kanduang, Reposition, Private Area, Skill

\section{PENDAHULUAN}

Matematika merupakan salah satu mata pelajaran yang dianggap sulit dan sukar oleh sebagian besar siswa dan hal ini disebabkan oleh sifatnya yang abstrak, penuh angka, rumus, dan memerlukan latihan. Sehingga dengan sifat matematika yang demikian akhirnya siswa sering mengalami kecemasan dalam belajar matematika. Kecemasan yang dialami siswa pada mata pelajaran matematika sering disebut sebagai math anxiety. Tanda-tanda math menurut Indiyani, dkk (2006. P.15) adalah (1) Gejala fisik seperti : tegang saat mengerjakan soal matematika, gugup, berkeringat, tangan gemetar ketika harus menyelesaikan soal matematika atau ketika mulai pelajaran matematika, (2) Gejala kognitif seperti : pesimis dirinya tidak mampu mengerjakan soal matematika, khawatir kalau hasil pekerjaan matematikanya buruk, tidak yakin dengan pekerjaan matematikanya sendiri, ketakutan menjadi bahan tertawaan jika tidak mampu mengerjakan soal matematika, (3) Gejala Perilaku seperti siswa berdiam diri karena takut ditertawakan, tidak mau mengerjakan soal matematika karena takut gagal lagi, dan menghindari pelajaran matematika.

Kecemasan terhadap matematika tidak bisa dipandang sebagai hal biasa, karena ketidakmampuan siswa dalam beradaptasi pada pelajaran menyebabkan siswa kesulitan serta fobia terhadap matematika yang akhirnya menyebabkan hasil belajar dan prestasi siswa dalam matematika rendah (Wahyu, 2014. p. 126). Faktor yang mempengaruhi math anxiety terhadap matematika terdiri dari faktor internal dan faktor eksternal. Faktor eksternalnya yaitu seperti lingkungan sekitar siswa, sedangkan faktor internalnya yaitu seperti perbedaan gender, psikis dan emosional siswa. Melalui faktor-faktor tersebut guru harus mampu meyeimbangkan kemampuan siswa baik secara mental, keterampilan, dan pengetahuan yang berbeda setiap siswanya, khususnya pada 
faktor perbedaan gender. Perbedaan gender tentu akan menyebabkan perbedaan fisiologi dan mempengaruhi perbedaan psikologis dalam belajar. Sehingga siswa laki-laki dan perempuan tentu memiliki banyak perbedaan dalam mempelajari matematika.

Nafi' an (dalam Amir. 2013. P.16) menjelaskan bahwa adanya perbedaan antara laki-laki dan perempuan dalam belajar matematika sebagai berikut : 1) Laki-laki lebih unggul dalam penalaran, sedangkan perempuan lebih unggul dalam ketepatan, ketelitian, kecermatan, dan keseksamaan berpikir. 2) Laki-laki memiliki kemampuan matematika dan mekanika yang lebih baik dari pada perempuan, perbedaan ini tidak nyata pada tingkat sekolah dasar akan tetapi menjadi tampak lebih jelas pada tingkat yang lebih tinggi dalam hal matematika, namun perempuan lebih unggul dalam aspek efektifnya (tekun, teliti, cermat) .

Math Anxiety sangat berpengaruh terhadap hasil belajar matematika dan prestasi siswa dalam matematika rendah (Handayani, 2016. P.24). Untuk mencapai hasil belajar matematika yang baik maka diperlukan kemampuan-kemampuan matematis diantaranya kemampuan pemahaman konsep matematis, kemampuan penalaran matematis, kemampuan komunikasi matematis, kemampuan koneksi matematis, kemampuan pemecahan masalah, dan kemampuan representasi matematis siswa. Diantara kemampuankemampuan matematis tersebut, kemampuan yang paling mendasar yang harus dikuasai oleh siswa terlebih dahulu yaitu kemampuan pemahaman konsep matematis, dikarenakan kemampuan pemahaman konsep matematis ini adalah kemampuan yang paling mendasar yang harus dikuasai siswa, karena dalam mempelajari matematika peserta didik harus memahami konsep matematika terlebih dahulu agar dapat menyelesaikan soal-soal dan mampu mengaplikasikan pembelajaran tersebut di dunia nyata dan mampu mengembangkan kemampuan lain yang menjadi tujuan dari pembelajaran matematika (Murizal, dkk. 2012. P.20). Pemahaman terhadap konsep-konsep matematika merupakan dasar untuk belajar matematika secara bermakna.

Berdasarkan hasil observasi di kelas VIII MTsN 07 Tanah Datar pada aspek gender, terlihat indikasi perbedaan math anxiety siswa laki-laki dan perempuan. Terlihat ketika siswa perempuan ketika diberitahukan bahwa ada latihan ataupun ulangan yang akan diberikan oleh guru, siswa perempuan terlihat cemas dan panik, kemudian siswa-siswa perempuan langsung melihat catatan matematikanya dan menghafal sebentar. Sedangkan siswa lakilaki, terlihat santai dan tidak terlihat wajah cemas ketika diberi tahu akan ada ulangan atau latihan yang diberikan. Ketika ulangan matematika berlangsung, kebanyakan siswa perempuan fokus dan berkonsentrasi dalam membuat ulangan tersebut, sedangkan siswa laki-laki mereka melihat kanan kiri atau mencontek untuk memperoleh hasil ulangannya tersebut.

Berdasarkan hal tersebut, pada artikel ini mengkaji(1)Apakah terdapat perbedaan math anxiety siswa laki-laki dan siswa perempuan? (2)Apakah terdapat perbedaan kemampuan pemahaman konsep matematis siswa laki-laki dan siswa perempuan? (3)Apakah terdapat pengaruh math anxiety terhadap kemampuan pemahaman konsep matematis pada siswa laki-laki? (4)Apakah terdapat pengaruh math anxiety terhadap kemampuan pemahaman konsep matematis pada siswa perempuan?

\section{METODE}

Penelitian ini adalah penelitian lapangan (field research) dengan metode korelasional, yaitu penelitian untuk menemukan ada tidaknya hubungan dan apabila ada, berapa eratnya hubungan serta berarti atau tidaknya hubungan itu Arikunto (2006. P.270). Hubungan yang akan dilihat dalam penelitian ini yaitu hubungan antara math anxiety terhadap kemampuan pemahaman konsep matematis siswa lakilaki dan hubungan antara math anxiety 
terhadap kemampuan pemahaman konsep matematis siswa perempuan kelas VIII MTsN 07 Tanah Datar. Sampel dipilih dengan teknik simple random sampling.
Instrumen yang digunakan adalah angket math anxiety dan tes kemampuan pemahaman konsep. Kisi- kisi angket dapat dilihat pada tabel 1:

Tabel 1: Kisi-kisi angket math anxiety

\begin{tabular}{|c|c|c|c|c|}
\hline Nomor & Gejala Kecemasan & Indikator & No Item & Jumlah \\
\hline 1 & $\begin{array}{l}\text { Gejala } \\
\text { Fisik/Emotinally }\end{array}$ & a. Tegang & $1,8,14$ & \multirow[t]{4}{*}{10} \\
\hline & & b. Gugup & $6,18,20$ & \\
\hline & & c. Berkeringat & 19,29 & \\
\hline & & d. Gemetar & 11,16 & \\
\hline \multirow[t]{4}{*}{2} & Gejala Kognitif/Worry & a. Pesimis & 9,23 & \multirow[t]{4}{*}{9} \\
\hline & & b. Khawatir & $17,25,28,32$ & \\
\hline & & c. Tidak Yakin & 2,15 & \\
\hline & & d. Takut & 7 & \\
\hline \multirow[t]{3}{*}{3} & Gejala Perilaku & a. Berdiam Diri & 24,26 & \multirow[t]{3}{*}{7} \\
\hline & & b. Tidak mau bekerja & 22 & \\
\hline & & c. Menghindar & $5,10,13,30$ & \\
\hline \multicolumn{4}{|c|}{ Jumlah } & 27 \\
\hline
\end{tabular}

Tes kemampuan pemahaman konsep yang dirancang mengacu pada kisi-kisi seperti terlihat pada tabel 2:

Tabel 2: Kisi-kisi tes kemampuan pemahaman konsep

\begin{tabular}{|c|c|c|}
\hline Kompetensi Dasar & $\begin{array}{l}\text { Indikator Kemampuan } \\
\text { Pemahaman Konsep }\end{array}$ & Nomor Soal \\
\hline \multirow{7}{*}{$\begin{array}{l}\text { 1. Menjelaskan peluang } \\
\text { empirik dan teoritik suatu } \\
\text { kejadian dari suatu } \\
\text { percobaan } \\
\text { 2. Menyelesaikan masalah } \\
\text { yang berkaitan dengan } \\
\text { peluang empirik dan } \\
\text { teoritik suatu kejadian dari } \\
\text { suatu percobaan }\end{array}$} & $\begin{array}{l}\text { 1. Menyatakan Ulang Sebuah } \\
\text { Konsep }\end{array}$ & 1 \\
\hline & $\begin{array}{l}\text { 2. Mengklasifikasikan objek- } \\
\text { objek menurut sifat-sifat } \\
\text { tertentu (sesuai dengan } \\
\text { konsepnya) }\end{array}$ & 2 \\
\hline & $\begin{array}{l}\text { 3. Member contoh dan non } \\
\text { contoh dari konsep }\end{array}$ & 3 \\
\hline & $\begin{array}{l}\text { 4. Menyajikan konsep dalam } \\
\text { berbagai representasi } \\
\text { matematis }\end{array}$ & 4 \\
\hline & $\begin{array}{l}\text { 5. Mengembangkan syarat } \\
\text { perlu atau syarat cukup } \\
\text { suatu konsep }\end{array}$ & 5 \\
\hline & $\begin{array}{l}\text { 6. Menggunakan dan } \\
\text { memanfaatkan serta } \\
\text { memilih prosedur atau } \\
\text { operasi tertentu } \\
\end{array}$ & 6 \\
\hline & $\begin{array}{l}\text { 7. Mengaplikasikan konsep } \\
\text { atau algoritma dalam } \\
\text { pemecahan masalah }\end{array}$ & 7 \\
\hline
\end{tabular}


Hipotesis yang diajukan pada penelitian ini adalah: 1) terdapat perbedaan perbedaan math anxiety siswa laki-laki dan siswa perempuan, 2) terdapat perbedaan perbedaan kemampuan pemahaman konsep matematis siswa laki-laki dan siswa perempuan, 3) terdapat pengaruh math anxiety terhadap kemampuan pemahaman konsep matematis pada siswa laki-laki, 4) terdapat pengaruh math anxiety terhadap kemampuan pemahaman konsep matematis pada siswa perempuan. Data yang diperoleh dari angket dan tes kemampuan pemahaman konsep matematis dianalisis untuk menemukan pengaruh dari math anxiety siswa terhadap kemampuan pemahaman konsep matematis siswa berdasarkan gender pada kelas VIII MTsN 07 Tanah Datar. Untuk menguji hipotesis (1) dan (2)

\section{Tabel 3: Hasil Angket Math} Anxiety

\begin{tabular}{|l|l|l|}
\hline Deskripsi & Laki-Laki & Perempuan \\
\hline Jumlah & 10 & 10 \\
\hline Nilai Minimum & 65 & 98 \\
\hline $\begin{array}{l}\text { Nilai } \\
\text { Maksimum }\end{array}$ & 115 & 122 \\
\hline $\begin{array}{l}\text { Jumlah Skor } \\
\text { Angket }\end{array}$ & 929 & 1104 \\
\hline Rata-rata & 92.90 & 110.40 \\
\hline Variansi & 165.21 & 72.93 \\
\hline
\end{tabular}

Untuk kemampuan pemahaman konsep dapat dilihat pada Tabel 4 berikut:

\section{Tabel 4: Hasil Tes Kemampuan} Pemahaman Konsep Siswa

\begin{tabular}{|l|l|l|}
\hline Deskripsi & Laki-Laki & Perempuan \\
\hline Jumlah & 10 & 10 \\
\hline Nilai Minimum & 3 & 7 \\
\hline $\begin{array}{l}\text { Nilai } \\
\text { Maksimum }\end{array}$ & 75 & 96 \\
\hline Rata-rata & 48.62 & 40 \\
\hline Variansi & 902.53 & 886.66 \\
\hline
\end{tabular}

1. Perbedaan math anxiety siswa laki-laki dan perempuan dilakukan dengan uji $t$ dua arah. Sedangkan untuk menguji hipotesis (3) dan (4) dilakukan dengan uji korelasi dengan menggunakan SPSS 16.0. Kemudian diukur seberapa besar pengaruh math anxiety terhadap kemampuan pemahaman konsep matematis siswa. Perhitungan ini menggunakan rumus:

\section{koefisien determinasi $=r^{2} \times 100 \%$}

\section{HASIL PENELITIAN DAN PEMBAHASAN}

Data math anxiety $(X)$ diperoleh melalui angket yang diisi oleh siswa sedangkan data kemampuan pemahaman konsep $(Y)$ diperoleh melalui tes. Hasil Math Anxiety siswa laki-laki dan perempuan dapat dilihat pada Tabel 3:

Untuk membuktikan hipotesis yang dirancang, maka pada hipotesis pertama yaitu memperlihatkan adanya perbedaan math anxiety berdasarkan gender maka dilakukan tiga tahap uji sebagai berikut: 1) uji normalitas, 2) uji homogenitas dan 3) uji hipotesis. Hasil dari uji hipotesis yang pertama dengan $P$ valuenya 0,002 dan hipotesis diterima yaitu terdapat perbedaan math anxiety siswa laki-laki dan math anxiety siswa perempuan. Menurut Myers (1983) dalam Siska (2003. P.68) menyatakan bahwa perempuan lebih cemas akan ketidakmampuannya dibanding dengan laki-laki. Laki-laki lebih aktif, eksploratif, sedangkan perempuan lebih sensitif. Jadi, dapat disimpulkan bahwa adanya perbedaan math anxiety berdasarkan gender. Siswa perempuan cenderung memiliki math anxiety yang lebih tinggi daripada siswa laki-laki.

2. Perbedaan kemampuan pemahaman konsep siswa

Untuk membuktikan hipotesis kedua yaitu terdapat perbedaan kemampuan pemahaman konsep matematis siswa berdasarkan gender juga melalui tiga tahap yang sama dengan yang diatas yaitu: 1) uji 
normalitas, 2) uji homogenitas dan 3) uji hipotesis. Hasil dari uji hipotesis yang pertama dengan $P$ value nya 0,528 yaitu terdapat perbedaan kemampuan pemahaman konsep matematis siswa laki-laki dan kemampuan pemahaman konsep matematis siswa perempuan. Pada penelitian ini, ditemukan bahwa rata-rata siswa laki-laki memiliki kemampuan pemahaman konsep matematis lebih tinggi dibandingkan dengan siswa perempuan.

3. Pengaruh math anxiety terhadap kemampuan pemahaman konsep matematis siswa laki-laki

Selanjutnya untuk membuktikan hipotesis ketiga yaitu terdapat pengaruh math anxiety terhadap kemampuan pemahaman konsep matematis siswa lakilaki dilakukan dengan beberapa cara yakni: 1) Uji normalitas melihat hasil angket math anxiety dan tes kemamuan pemahaman konsep matematis berdistribusi normal , 2) Uji linieritas siswa laki-laki memperoleh Fhitung $=0,359$ dan $F_{\text {tabel }}=4,75$, dapat diartikan bahwa math anxiety dan kemampuan pemahaman konsep matematis siswa berdistribusi linier, 3) Uji Korelasi memperlihatkan pengaruh dari math anxiety terhadap kemampuan pemahaman konsep matematis.

\section{Tabel 5. Uji Correlation Product Moment Siswa Laki-Laki}

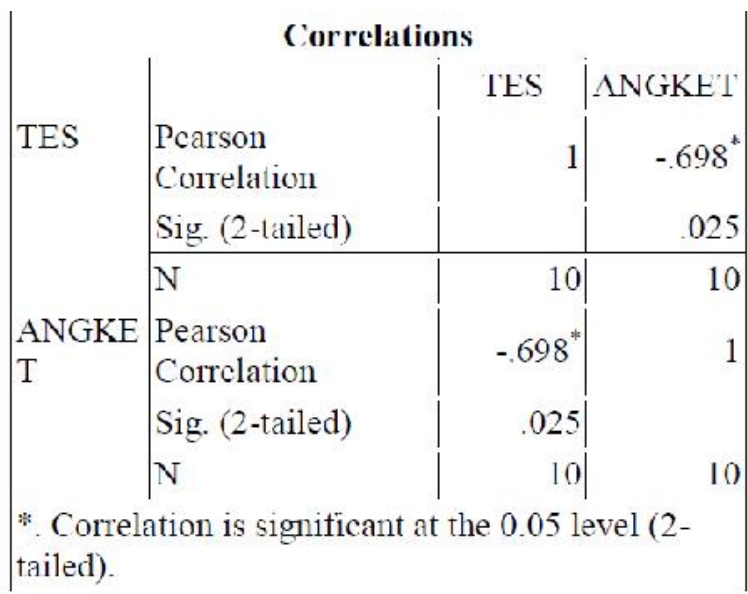

Dari tabel 5 diperoleh bahwa hasil uji korelasi math anxiety terhadap kemampuan pemahaman konsep matematis siswa laki-laki yaitu $-0,698$, artinya semakin tinggi math anxiety seseorang siswa laki-laki maka semakin rendah kemampuan pemahaman konsep matematis siswa lakilaki tersebut. Selanjutnya dilakukan dengan tahap uji signifikan, koefisien determinasi dan persamaan regresi pada siswa laki-laki. Jika dikaitkan dengan interprestasi besarnya $r$-ProductMoment, dengan pengaruh math anxiety terhadap kemampuan pemahaman konsep matematis siswa sebesar 48,72\% tergolong cukup dan selebihnya itu dipengaruhi oleh faktor lain.

4. Pengaruh math anxiety terhadap kemampuan pemahaman konsep matematis siswa perempuan

Untuk membuktikan hipotesis keempat yaitu terdapat pengaruh math anxiety terhadap kemampuan pemahaman konsep matematis siswa perempuandilakukan dengan beberapa cara yakni: 1) Uji normalitas melihat hasil angket math anxiety dan tes kemamuan pemahaman konsep matematis berdistribusinormal , 2) Uji linieritas siswa laki-laki memperoleh Fhitung $=3,263$ dan $F_{\text {tabel }}=4,75$, dapat diartikan bahwa math anxiety dan kemampuan pemahaman konsepmatematis siswa perempuan berdistribusi linier, 3) Uji Korelasi memperlihatkan pengaruh dari math anxiety terhadap kemampuan pemahaman konsep matematis,dan didapatkan hasil korelasi math anxiety terhadap kemampuan pemahaman konsep matematis siswa perempuan pada Tabel 6:

Tabel 6. Uji Correlation Product Moment Siswa Perempuan

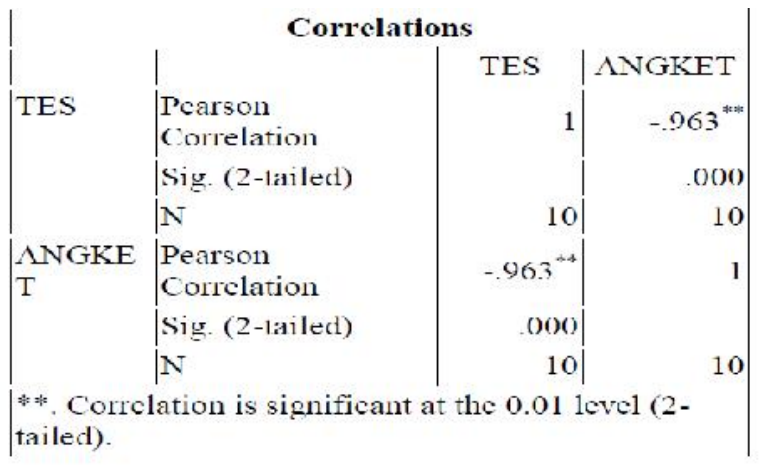


Dari Tabel 6 terlihat bahwa hasil uji korelasi kecemasan matematika(math anxiety) terhadap kemampuan pemahaman konsep matematis siswa perempuan yaitu 0,963. Artinya semakin tinggi math anxiety siswa perempuan maka semakin rendah kemampuan pemahaman konsep matematis siswa perempuan tersebut. Selanjutnya dilakukan dengan tahap uji signifikan, koefisien determinasi dan persamaan regresi pada siswa perempuan. Jika dikaitkan dengan interprestasi besarnya r-Product Moment, dengan pengaruh math anxiety terhadap kemampuan pemahaman konsep matematis siswa sebesar $92,73 \%$ tergolong sangat tinggi dan selebihnya itu dipengaruhi oleh faktor lain.

Hasil penelitian ini sejalan dengan hasil penelitian Munasiah (2015. p.230) menjelaskan bahwa adanya pengaruh langsung yang negatif kecemasan belajar terhadap pemahaman konsep matematika. Semakin tinggi tingkat kecemsan seseorang, maka semakin rendahlah kemampuan pemahaman konsep siswa tersebut. Karena untuk meningkatkan kemampuan pemahaman konsep matematika siswa, maka salah satunya siswa harus mampu mengurangi perasaan cemas dari dalam diri mereka serta guru juga mampu menciptakan suasana yang menyenangkan.

Berdasarkan pengaruh math anxiety terhadap kemampuan pemahaman konsep berdasarkan gender pada penelitian ini dapat dipahami bahwa terdapat pengaruh kecemasan siswa saat menghadapi mata pelajaran matematika terhadap kemampuan pemahaman konsep matematis siswa baik itu siswa laki-laki maupun siswa perempuan. Menurut Budi, dkk (2013, p. 90) menyatakan bahwa kecemasan adalah salah satu alasan mengapa hubungan interpersonal yang baik penting dalam memahami matematika. Hal tersebut karena kecemasan tersebut dapat meningkat, bersifat subjektif pada setiap individu, dan mempengaruhi sulit atau tidaknya pemahaman. Dalam penelitian ini math anxiety memiliki dampak yang berbeda terhadap laki-laki dan perempuan, dimana math anxiety berpengaruh lebih besar terhadap kemampuan pemahaman konsep siswa perempuan dari pada siswa laki-laki.

\section{KESIMPULAN DAN REKOMENDASI}

Berdasarkan penelitian yang telah dilakukan dapat disimpulkan bahwa: 1)Terdapat perbedaan kecemasan matematika (math anxiety) siswa laki-laki dengan siswa perempuan, dengan nilai $P$ Value nya 0,002. 2)Terdapat perbedaan kemampuan pemahaman konsep matematis siswa laki-laki dengan siswa perempuan, dengan nilai $P$-Value nya 0,528 . 3)Terdapat pengaruh math anxiety terhadap kemampuan pemahaman konsep matematis siswa lakilaki. 4) Terdapat pengaruh math anxiety terhadap kemampuan pemahaman konsep matematis siswa perempuan.

\section{DAFTAR KEPUSTAKAAN}

Amir, Zubaidah. (2013).Perspektif Gender Dalam Pembelajaran matematika. UPI Bandung.

Arikunto, Suharsimi. (2006). Prosedur Penelitian Suatu Pendekatan Praktik. PT. Rineka Cipta : Jakarta.

Budi, Arief Wicaksono, dkk. (2013). Mengelola Kecemasan Siswa dalam Pembelajaran Matematika. Prosiding. ISBN: 978-979-163539-4.

Handayani, Shinta Dwi. (2016). Pengaruh Konsep Diri dan Kecemasan Siswa Terhadap Pemecahan Konsep Matematika. Jurnal Formatif, 6(1), ISSN:2088-351x

Indiyani, Novita Eka, dkk. (2006). Efektifitas Metode Pembelajaran Gotong Royong (Cooperative Learning) Untuk Menuntun dan Kecemasan Siswa dalam Menghadapi Pelajaran 
Matematika. Jurnal Psikologi Universitas Diponegoro.

Mawaddah, Siti. (2016). Kemampuan Pemahaman Konsep Matematis Siswa SMP dalam Pembelajaran Menggunakan Model Penemuan Terbimbing (Discovery Learning). Jurnal Pendidikan Matematika 4(1): 76-85

Munasiah. (2015). Pengaruh Kecemasan Belajar Dan Pemahaman Konsep Matematika Siswa Terhadap Kemampuan Penalaran
Matematika. Jurnal Formatif, 5(3), ISSN : 2088-531x

Siska, Sudardjo \& Esti Hayu Purnamaningsih. (2003). Kepercayaan Diri dan Kecemasan Komunikasi Interpersonal pada Mahasiswa. Jurnal Psikologi (2). 67-71

Wahyu, Ika Anita. (2014). Pengaruh Kecemasan Matematika(math anxiety) terhadap kemampuan koneksi siswa SMP. Jurnal Ilmiah Program Studi Matematika STKIP Siliwangi Bandung. 